\title{
IMPLEMENTASI PEMBELAJARAN FISIKA SMA BERBASIS INKUIRI TERBIMBING TERINTEGRASI PENDIDIKAN KARAKTER UNTUK MENINGKATKAN HASIL BELAJAR SISWA PADA MATERI CAHAYA DAN OPTIKA
}

\author{
Ardian Asyhari $^{1}$, Risa Hartati ${ }^{2}$ \\ ${ }^{1}$ Program Studi Pendidikan Fisika, FTK IAIN Raden Intan Lampung, Email: ardianasyhari@ gmail.com \\ ${ }^{2}$ Alumni Program Studi Pendidikan IPA, Sekolah Pascasarjana UPI Bandung, Email: risahartati@gmail.com
}

\begin{abstract}
Abstrak: Penelitian ini bertujuan untuk mendeskripsikan hasil belajar siswa (hasil belajar kognitif, afektif, dan hasil belajar psikomotor) melalui penerapan pembelajaran berbasis inkuiri terbimbing terintegrasi pendidikan karakter. Pencapaian hasil belajar siswa yang diukur terdiri dari tiga aspek, yaitu aspek kognitif, psikomotorik, dan afektif. Instrumen penelitian yang digunakan pada penelitian ini terdiri dari soal pretest dan posttest (aspek kognitif), lembar penilaian psikomotorik (aspek psikomotorik), dan lembar penilaian afektif (karakter). Teknik analisis data dilakukan dengan menggunakan program IBM SPSS Statistics 22. Untuk analisis data kognitif dilakukan dengan menggunakan uji normalitas, uji homogenitas, dan uji $\mathrm{t}$ berpasangan (paired sample $\mathrm{t}$-test) terhadap data pretest dan post-test, sedangkan analisis data psikomotorik dan afektif peserta didik tiap pertemuan dianalisis menggunakan uji Friedman. Hasil penelitian ini menunjukkan bahwa perlakuan yang diberikan dapat meningkatkan hasil belajar siswa (hasil belajar kognitif, afektif, dan hasil belajar psikomotor) pada materi cahaya dan optika.
\end{abstract}

Kata Kunci: cahaya dan optika, inkuiri terbimbing, pendidikan karakter

\section{PENDAHULUAN}

Kebutuhan guru akan metode pembelajaran yang dapat menunjang aktivitas dan kreativitas peserta didik pada kegiatan pembelajaran sangat tinggi. Kebutuhan tersebut merupakan suatu kesadaran yang penting bagi guru untuk menyiapkan dan membekali para peserta didik mereka. Hasil penelitian oleh Kuhlthau et al. (2007) menjelaskan bahwa cara baru dalam pembelajaran sangat dibutuhkan untuk menyiapkan peserta didik dalam lingkungan dan budaya kerja yang kompleks di era perkembangan teknologi informasi dan globalisasi sekarang ini.

Terdapat banyak perkembangan inovatif dalam dunia pendidikan yang dapat menunjang pembelajaran dan mengadvokasi kebutuhan akan pendidikan karakter dan peningkatan hasil belajar, sebagai contohnya adalah penerapan inkuiri dalam pembelajaran. Inkuiri adalah suatu proses dimana peserta didik secara aktif menginvestigasi dunianya melalui bertanya dan mencari jawaban atas berbagai pertanyaan. Proses ini dilakukan dengan mengajukan pertanyaan, melakukan penelusuran jawaban, eksplorasi, dan investigasi (Mertelino et al. 2000 dalam Suyatna, 2015). Metode pembelajaran inkuiri menuntut peserta didik untuk terlibat secara aktif dalam proses pembelajaran, sehingga peserta didik akan lebih menghargai dan meresapi hal-hal baru yang mereka peroleh dari proses pembelajaran berbasis inkuiri yang telah dilalui. Menurut Hamalik (2009), peserta didik akan mendapatkan pengalaman dengan keterlibatan secara aktif dan pribadi 
daripada yang diperoleh dengan melihat atau menonton isi dan konsep.

Menurut Trowbridge et al. (dalam Suyatna, 2015), ditinjau dari tingkat kompleksitasnya, pembelajaran dengan inkuiri dibedakan menjadi tiga tingkatan. Tingkatan pertama adalah pembelajaran penemuan (discovery). Tingkatan kedua adalah pembelajaran inkuiri terbimbing (guided inquiry), dan tingkatan yang paling kompleks adalah inkuiri terbuka atau bebas (open inquiry). Dalam pembelajaran penemuan (discovery), peserta didik diajak melakukan pencarian konsep melalui kegiatan yang melibatkan pertanyaan, inferensi, prediksi, berkomunikasi, interpretasi, dan menyimpulkan. Dalam pembelajaran inkuiri terbimbing (guided inquiry) masalah dimunculkan oleh pembimbing atau oleh guru. Sementara dalam pembelajaran inkuiri terbuka atau inkuiri bebas (open inquiry), masalah berasal dari peserta didik dengan bantuan dan arahan dari guru sampai peserta didik menemukan jawaban dari hal yang dipertanyakan dan mungkin berakhir dengan pertanyaan dan masalah baru yang perlu ditindaklanjuti pada kegiatan pembelajaran berikutnya.

Tingkatan inkuiri yang relatif mudah untuk digunakan dan diterapkan dalam kegiatan pembelajaran adalah inkuiri terbimbing. Lebih lanjut menurut Kuhlthau et al. (2007). Pembelajaran Inkuiri Terbimbing adalah pembelajaran inkuiri yang telah direncanakan, ditargetkan, dan melibatkan intervensi serta pengawasan guru selama proses penyelidikan. Sehingga dengan adanya pengawasan dan keterlibatan guru, kegiatan pembelajaran akan lebih terarah pada pencapaian tujuan pembelajaran.
Penggunaan integrasi pendidikan karakter dalam pembelajaran inkuiri terbimbing dapat memberikan implikasi yang nyata terhadap berlangsungnya kegiatan pembelajaran. Hasil penelitian Panjaitan (2011) menyebutkan bahwa selain dapat meningkatkan hasil belajar peserta didik, pembelajaran inkuiri terbimbing terintegrasi pendidikan karakter juga dapat mendidik karakter peserta didik. Brooks dan Gobel (dalam Koesoema, 2010) menyatakan bahwa pendidikan karakter yang secara sistematis diterapkan dalam kegiatan pembelajaran merupakan daya tawar berharga bagi seluruh komunitas. Para peserta didik mendapatkan keuntungan dengan memperoleh perilaku dan kebiasaan positif yang mampu meningkatkan rasa percaya dalam diri mereka , membuat hidup mereka lebih bahagia dan lebih produktif.

Tujuan dari penelitian ini adalah mendeskripsikan hasil belajar siswa (hasil belajar kognitif, afektif, dan hasil belajar psikomotor) setelah diberi perlakuan berupa pembelajaran berbasis inkuiri terbimbing terintegrasi pendidikan karakter.

\section{METODE PENELITIAN}

\section{Desain Penelitian}

Penelitian ini merupakan penelitian weak experiment dengan desain penelitian one group pretest-posttest design, di mana hanya melibatkan satu kelas eksperimen saja untuk mengetahui pencapaian hasil belajar peserta didik setelah diterapkan pembelajaran fisika berbasis inkuiri terbimbing terintegrasi pendidikan karakter.

\section{Subjek Penelitian}

Populasi dari penelitian ini adalah seluruh kelas X yang terdaftar di salah satu SMA Negeri di Kota Surakarta. Penentuan sampel 
dilakukan dengan menggunakan teknik purposive sampling, sehingga diperoleh satu kelas yang terdiri dari 28 orang siswa.

\section{Instrumen Penelitian}

Pencapaian hasil belajar siswa yang diukur terdiri dari tiga aspek, yaitu aspek kognitif, psikomotorik, dan afektif. Instrumen penelitian yang digunakan pada penelitian ini terdiri dari soal pretest dan posttest untuk mengetahui pencapaian hasil belajar siswa pada aspek kognitif, lembar penilaian psikomotorik untuk mengetahui pencapaian hasil belajar siswa pada aspek psikomotorik., dan lembar penilaian afektif (karakter) untuk mengetahui pencapaian hasil belajar siswa pada aspek afektif.

\section{Prosedur Penelitian}

Penelitian ini dilakukan selama lima kali pertemuan. Kegiatan penelitian diawali dengan tes awal (pretest) yang bertujuan untuk mengetahui kemampuan awal siswa yang dilakukan selama satu kali pertemuan. Kemudian proses pembelajaran dilaksanakan selama tiga kali pertemuan tatap muka dengan tujuan penguasaan materi pembelajaran pada materi cahaya dan optika. Selama kegiatan pembelajaran dilaksanakan, siswa diamati oleh pengamat untuk dinilai aspek psikomotorik dan afektifnya. Kegiatan penelitian diakhiri dengan tes akhir (post-test) yang bertujuan untuk mengetahui apakah kelas eksperimen memiliki peningkatan pencapaian hasil belajar setelah diterapkan pembelajaran berbasis inkuiri terbimbing reintegrasi pendidikan karakter.

\section{Analisis Data}

\section{Data kognitif peserta didik}

Data kognitif peserta didik diperoleh dari nilai pretest dan posttest. Data pretest dan postest peserta didik diuji normalitas dan homogenitasnya. Pengujian ditujukan sebagai bentuk uji prasyarat analisis. Data yang digunakan berupa data rasio yang termasuk dalam data kuantitatif. Hasil dari uji prasyarat digunakan sebagai dasar analisis lebih lanjut terhadap nilai hasil belajar peserta didik. Seluruh pengujian dalam analisis menggunakan program IBM SPSS Statistik 20.

\section{a. Uji Normalitas}

Uji normalitas digunakan untuk mengetahui pola sebaran kelompok data tes yang dihasilkan. Hasil uji kenormalan menggunakan hasil pada KolmogorovSmirnov ${ }^{a}$. Pengujian diawali dengan memberikan hipotesis terhadap nilai signifikansi.

Ho : data terdistribusi normal

$\mathrm{Ha}$ : data tidak terdistribusi normal

Jika nilai signifikansi yang diperoleh lebih besar dari $\alpha=0,05$ (Sign. > 0,05) maka Ho diterima.

\section{b. Uji Homogenitas}

Uji homogenitas digunakan untuk mengetahui kesamaan dalam variansi data. Pengujian homogenitas data dilakukan dengan uji Levene. Hipotesis diberikan pada data yang dilihat variannya.

Ho : Varian data homogen

Ha : Varian data tidak homogen

Ketentuan uji yaitu Ho diterima jika nilai signifikansi yang diperoleh lebih besar dari $\alpha=0,05$ (Sign. $>0,05$ ).

\section{c. Uji Dua Sampel Berpasangan}

Skor pretest dan posttest melalui tahapan uji $\mathrm{t}$ dengan dua sampel 
berpasangan (paired sample t-test). Priyatno (2009) menyebutkan paired sample t-test digunakan untuk mengetahui ada tidaknya perbedaan antara dua variabel yang berpasangan. Hipotesis yang diberikan untuk pengujiannya adalah sebagai berikut:

Ho : Hasil belajar kognitif sebelum dan sesudah pembelajaran berbasis inkuiri terbimbing adalah sama

Ha : Hasil belajar kognitif sebelum dan sesudah pembelajaran berbasis inkuiri terbimbing adalah tidak sama

Terdapat 2 kriteria pengambilan keputusan yang akan digunakan, yang pertama yaitu berdasarkan perbandingan $\mathrm{t}_{\text {hitung }}$ dan $\mathrm{t}_{\text {tabel }}$, ketentuannya adalah jika $t_{\text {tabel }}<t_{\text {hitung }}<t_{\text {tabel }}$, maka Ho diterima, dan jika $t_{\text {hitung }}<-t_{\text {tabel }}$ atau $-t_{\text {hitung }}>t_{\text {tabel }}$, maka Ho ditolak. Pengambilan keputusan yang kedua, yaitu berdasarkan nilai probabilitas, jika nilai probabilitas > 0,05, maka Ho diterima, sebaliknya jika nilai probabilitas $<0,05$, maka Ho ditolak.

\section{Data Psikomotorik Peserta Didik}

Analisis penilaian psikomotorik peserta didik dilakukan untuk mengetahui pencapaian keterampilan psikomotorik yang aspek dan indikator telah disesuaikan dengan tujuan penelitian. Aspek-aspek tersebut mengarah pada ketercapaian keterampilan proses sains dan keterampilan sosial peserta didik. Skor yang diberikan mengacu pada 19 aspek penilaian. Masingmasing aspek memiliki rentang skor 1 sampai 4. Lembar penilaian psikomotorik untuk peserta didik diisi oleh guru (observer) terhadap masing-masing peserta didik dalam kelompok yang diamati untuk selanjutnya dianalisis sebagai pencapaian keterampilan psikomotorik. Kategori penilaian psikomotorik yang di adaptasi dan dikembangkan dari Kemendiknas (2010) disajikan pada Tabel 1.

Tabel 1. Kategori Penilaian Psikomotorik Peserta Didik

\begin{tabular}{cc}
\hline $\begin{array}{c}\text { Rentang } \\
\text { Skor }\end{array}$ & Kategori \\
\hline $19-33$ & Gagal \\
$34-47$ & Kurang Berhasil \\
$48-61$ & Berhasil \\
$62-76$ & Sangat Berhasil \\
\hline
\end{tabular}

Selain menggunakan kategori penilaian, hasil psikomotorik peserta didik tiap pertemuan juga dianalisis menggunakan uji Friedman, yaitu uji nonparametric untuk menguji data tiga atau lebih sampel berhubungan. Hipotesis pengujiannya adalah sebagai berikut:

Ho: Hasil penilaian psikomotorik tiap pertemuan adalah sama

Ha: Hasil penilaian psikomotorik tiap pertemuan adalah tidak sama

Pengambilan keputusan yang akan digunakan, yang pertama yaitu berdasarkan perbandingan $t_{\text {hitung }}$ dan $t_{\text {tabel }}$, ketentuannya adalah jika $t_{\text {hitung }}<t_{\text {tabel }}$, maka Ho diterima, dan jika $t_{\text {hitung }}>t_{\text {tabel }}$, maka Ho ditolak. Pengambilan keputusan yang kedua, yaitu berdasarkan nilai probabilitas, jika nilai probabilitas > 0,05, maka Ho diterima, sebaliknya jika nilai probabilitas $<0,05$, maka Ho ditolak.

\section{Data Afektif Peserta Didik}

Analisis penilaian afektif dimaksudkan untuk melihat seberapa besar pencapaian peserta didik terkait pembentukan karakter mereka selama mengikuti proses pembelajaran. Penilaian mengarah pada 4 aspek karakter dalam pembelajaran yang 
diharapkan muncul selama kegiatan pembelajaran berlangsung. Masing-masing aspek dengan rentang skor 1 sampai 4 . Lembar penilaian afektif untuk peserta didik diisi oleh guru (observer) terhadap masingmasing peserta didik dalam kelompok yang diamati untuk selanjutnya dianalisis sebagai pencapaian karakter. Kategori penilaian afektif di adaptasi dan dikembangkan dari Kemendiknas (2010) disajikan pada Tabel 2.

Tabel 2.Kategori Penilaian Afektif Peserta didik

\begin{tabular}{cc}
\hline $\begin{array}{c}\text { Rentang } \\
\text { Skor }\end{array}$ & Kategori \\
\hline $4-7$ & Belum Terlihat \\
$8-10$ & Mulai Terlihat \\
$11-13$ & Mulai Berkembang \\
$14-16$ & Membudaya \\
\hline
\end{tabular}

Selain menggunakan kategori penilaian, hasil afektif peserta didik tiap pertemuan juga dianalisis menggunakan uji Friedman, yaitu uji nonparametric untuk menguji data tiga atau lebih sampel berhubungan. Hipotesis pengujiannya adalah sebagai berikut:

Ho: Hasil penilaian afektif tiap pertemuan adalah sama

Ha: Hasil penilaian afektif tiap pertemuan adalah tidak sama

Pengambilan keputusan yang akan digunakan, yang pertama yaitu berdasarkan perbandingan $t_{\text {hitung }}$ dan $t_{\text {tabel}}$, ketentuannya adalah jika $t_{\text {hitung }}<t_{\text {tabel }}$, maka Ho diterima, dan jika $t_{\text {hitung }}>t_{\text {tabel }}$, maka Ho ditolak. Pengambilan keputusan yang kedua, yaitu berdasarkan nilai probabilitas, jika nilai probabilitas > 0,05, maka Ho diterima, sebaliknya jika nilai probabilitas $<0,05$, maka Ho ditolak.

HASIL PENELITIAN

1) Data Hasil Belajar Kognitif
Deskripsi data hasil belajar kognitif yang diperoleh dari nilai pretest dan posttest, disajikan pada Tabel 3.

Tabel 3. Deskripsi Data Hasil Belajar Kognitif Peserta Didik

\begin{tabular}{cccccc}
\hline $\begin{array}{c}\text { Jenis } \\
\text { Tes }\end{array}$ & $\mathbf{N}$ & $\overline{\boldsymbol{X}}$ & SD & Min. & Maks. \\
\hline Pretest & 28 & 49,95 & 8,48 & 35,29 & 64,71 \\
\hline Posttest & 28 & 52,31 & 9,65 & 35,29 & 76,47 \\
\hline
\end{tabular}

Tabel 3. menyajikan data hasil belajar kognitif peserta didik sebelum dan sesudah diberikan pembelajaran berbasis inkuiri terbimbing yang telah dikembangkan. Sebelum diberi pembelajaran, hasil rerata yang diperoleh adalah 49,95 dengan standar deviasi 8,48, nilai terendah 35,29 dan tertinggi 64,71. Sedangkan setelah diberi pembelajaran berbasis inkuiri terbimbing yang telah dikembangkan, hasil rerata yang diperoleh peserta didik adalah 52,31 dengan standar deviasi 9,65, nilai terendah 35,29 dan tertinggi 76,47 .

Tabel 4. Distribusi Hasil Belajar Kognitif Peserta Didik

\begin{tabular}{cccccc}
\hline $\begin{array}{c}\text { Nilai } \\
\text { Interval }\end{array}$ & $\begin{array}{c}\text { Nilai } \\
\text { Tengah }\end{array}$ & $\begin{array}{c}\text { Frek. } \\
\text { Hasil } \\
\text { Pretest }\end{array}$ & $\begin{array}{c}\text { Frek. } \\
\text { Relatif } \\
\text { Pretest } \\
(\%)\end{array}$ & $\begin{array}{c}\text { Frek. } \\
\text { Hasil } \\
\text { Posttest }\end{array}$ & $\begin{array}{c}\text { Frek. } \\
\text { Relatif } \\
\text { Posttest } \\
(\%)\end{array}$ \\
\hline $35-40$ & 37,5 & 3 & 10,71 & 2 & 7,14 \\
\hline $41-46$ & 43,5 & 6 & 21,43 & 4 & 14,29 \\
\hline $47-52$ & 49,5 & 6 & 21,43 & 5 & 17,86 \\
\hline $53-58$ & 55,5 & 7 & 25,00 & 7 & 25,00 \\
\hline $59-64$ & 61,5 & 4 & 14,29 & 6 & 21,43 \\
\hline $65-70$ & 67,5 & 2 & 7,14 & 3 & 10,71 \\
\hline $71-77$ & 73,5 & 0 & 0,00 & 1 & 3,57 \\
\hline Jumlah & $\mathbf{2 8}$ & $\mathbf{1 0 0}$ & $\mathbf{2 8}$ & $\mathbf{1 0 0}$ \\
\hline
\end{tabular}




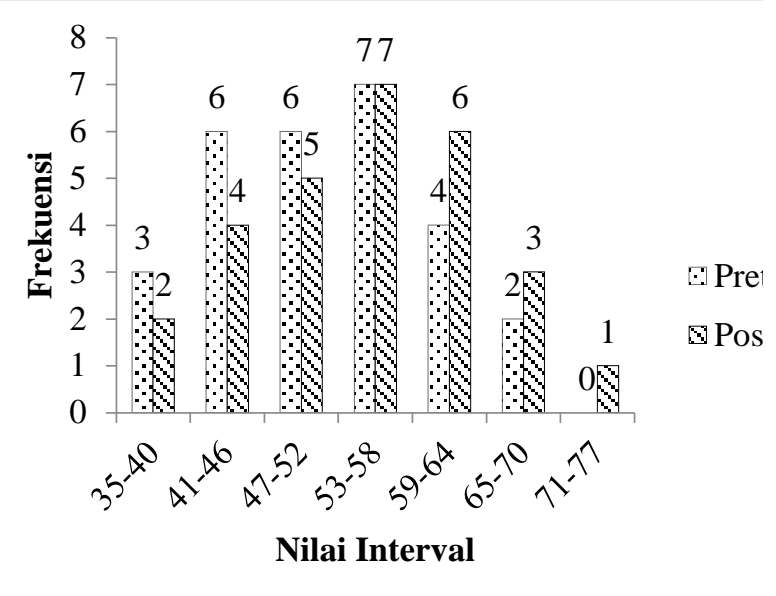

Gambar 1. Histogram Distribusi Frekuensi Hasil Pretest dan Posttest

Tabel 4. dan Gambar 1. menyajikan data distribusi hasil belajar peserta didik sebelum (pretest) dan sesudah (posttest) pembelajaran berbasis inkuiri terbimbing. Untuk pretest dan posttest, frekuensi tertinggi terletak pada interval 53-58 dengan jumlah frekuensi 7 , yaitu sebesar $25 \%$. Sedangkan untuk frekuensi terendah terletak pada interval 71-77 dengan jumlah frekuensi pada hasil pretest 0 atau sebesar $0 \%$, dan pada frekuensi hasil posttest 1 atau sebesar $3,57 \%$.

Ringkasan hasil analisis pretest dan posttest dapat dilihat pada Tabel 5 .

Tabel 5. Ringkasan Hasil Analisis Nilai Pretest dan Posttest

\begin{tabular}{|c|c|c|c|c|c|}
\hline No & $\begin{array}{l}\text { Yang } \\
\text { diuji }\end{array}$ & Jenis Uji & Hasil & $\begin{array}{c}\text { Keput } \\
\text { usan }\end{array}$ & $\begin{array}{c}\text { Kesimpu } \\
\text { lan }\end{array}$ \\
\hline 1 & $\begin{array}{l}\text { Norm } \\
\text { a-litas }\end{array}$ & $\begin{array}{c}\text { Kolmog } \\
\text { orov- } \\
\text { Smirno } \\
\mathrm{v}^{\mathrm{a}}\end{array}$ & $\begin{array}{c}\text { Sig. } \\
\text { Pretest } \\
=0,135 \\
\text { Sig. } \\
\text { Posttest } \\
=0.200\end{array}$ & $\begin{array}{c}\text { H0 } \\
\text { diteri } \\
\text { ma }\end{array}$ & $\begin{array}{c}\text { Data } \\
\text { normal }\end{array}$ \\
\hline 2 & $\begin{array}{c}\text { Homo } \\
- \\
\text { genita } \\
\text { s } \\
\end{array}$ & $\begin{array}{c}\text { Levene' } \\
\text { s test }\end{array}$ & $\begin{array}{l}\text { Sig. } \\
0.766\end{array}$ & $\begin{array}{c}\mathrm{H} 0 \\
\text { diteri } \\
\text { ma }\end{array}$ & $\begin{array}{l}\text { Data } \\
\text { homo- } \\
\text { gen }\end{array}$ \\
\hline 3 & $\begin{array}{l}\text { Hasil } \\
\text { Prete } \\
\text { st- } \\
\text { Postte } \\
\text { st }\end{array}$ & $\begin{array}{c}\text { Paired } \\
\text { Sample } \\
\text { t-test }\end{array}$ & $\begin{array}{c}\mathrm{t}_{\text {hitung }}= \\
-3,287 \\
\mathrm{p}= \\
0.003\end{array}$ & $\begin{array}{c}\mathrm{H} 0 \\
\text { ditola } \\
\mathrm{k}\end{array}$ & $\begin{array}{l}\text { Hasil } \\
\text { tidak } \\
\text { sama } \\
\text { (ada } \\
\text { perbe- } \\
\text { daan) }\end{array}$ \\
\hline
\end{tabular}

Berdasarkan ringkasan hasil analisis nilai pretest dan posttest yang disajikan pada Tabel 5., diketahui bahwa normalitas data yang di uji dengan Kolmogorov-Smirnov ${ }^{a}$, taraf signifikansi yang diperoleh untuk nilai pretest sebesar 0,135 dan posttest sebesar 0,200 , kedua nilai tersebut lebih besar dari $\alpha$ $=0,05$ (Sign. > 0,05) yang mengartikan bahwa Ho diterima. Sehingga dapat disimpulkan bahwa data nilai pretest dan posttest berdistribusi normal. Sedangkan untuk homogenitas data, hasil pretest dan posttest peserta didik di uji dengan menggunakan Levene's test, taraf signifikansi yang diperoleh adalah sebesar 0,766, lebih besar dari $\alpha=0,05$ (Sign. > $0,05)$ yang berarti bahwa Ho diterima. Sehingga dapat disimpulkan bahwa data nilai pretest dan posttest berasal dari populasi yang homogen atau variansi setiap sampel sama.

Data nilai pretest dan posttest yang telah diketahui berdistribusi normal dan berasal dari populasi yang homogen, selanjutnya dianalisis menggunakan uji $\mathrm{t}$ dua sampel berpasangan (Paired Sample t-test). Berdasarkan Tabel 5., diketahui $t_{\text {hitung }}$ adalah $-3,287$ sedangkan untuk $t_{\text {tabel }}(0,05 ; 27)$ adalah 2,052. Oleh karena $t_{\text {hitung }}<-t_{\text {tabel }}$ atau dengan melihat probabilitas sebesar 0,003 (p $<0,05)$, maka Ho ditolak. Hal ini berarti bahwa hasil belajar peserta didik sebelum dan sesudah diterapkan pembelajaran berbasis inkuiri terbimbing tidak sama, atau dengan ungkapan lain dapat dikatakan bahwa terdapat perbedaan yang signifikan antara hasil belajar peserta didik sebelum dan sesudah diterapkannya pembelajaran berbasis inkuiri terbimbing. Melihat nilai rerata posttest yang lebih besar dari nilai rerata pretest pada Tabel 3., dapat diketahui bahwa pembelajaran berbasis inkuiri 
terbimbing terintegrasi pendidikan karakter dapat meningkatkan hasil belajar kognitif peserta didik pada materi cahaya dan optika.

\section{2) Penilaian Psikomotorik}

Data hasil penilaian psikomotorik peserta didik yang diperoleh dari 3 kali pertemuan pada kelas uji coba diperluas, dideskripsikan pada Tabel 6.

Tabel 6. Deskripsi Data Pencapaian sikomotorik Peserta Didik

\begin{tabular}{cccccc}
\hline Pertemuan & N & Mean & SD & Min. & Maks. \\
\hline I & 28 & 47,68 & 3,34 & 40 & 54 \\
\hline II & 28 & 48,70 & 3,90 & 40 & 57 \\
\hline III & 28 & 48,79 & 2,25 & 43 & 53 \\
\hline
\end{tabular}

Tabel 6. menyajikan data pencapaian psikomotorik peserta didik selama pembelajaran berbasis inkuiri terbimbing berlangsung. Pada pertemuan pertama, hasil rerata yang diperoleh adalah 47,68 dengan standar deviasi 3,34, nilai terendah 40 dan tertinggi 54. Pada pertemuan kedua, hasil rerata yang diperoleh adalah 48,70 dengan standar deviasi 3,90, nilai terendah 40 dan tertinggi 57. Pada pertemuan ketiga, hasil rerata yang diperoleh adalah 48,79 dengan standar deviasi 2,25, nilai terendah 43 dan tertinggi 53.

Distribusi pencapaian psikomotorik peserta didik pada pertemuan I, II, dan pertemuan III (PI, PII, dan PIII), disajikan pada Tabel 7.

Tabel 7. Distribusi Pencapaian Psikomotorik Peserta Didik

\begin{tabular}{lccccc}
\hline Nilai Interval & $19-33$ & $34-47$ & $48-61$ & $62-76$ & \multirow{2}{*}{ Jumlah } \\
\cline { 1 - 5 } Kategori & Gagal & $\begin{array}{c}\text { Kurang } \\
\text { Berhasil }\end{array}$ & Berhasil & $\begin{array}{c}\text { Sangat } \\
\text { Berhasil }\end{array}$ & \\
\hline & 0 & 10 & 18 & 0 & 28 \\
\hline Hasil PI & 0 & 35,71 & 64,29 & 0 & 100 \\
\hline Relatif PI (\%) & 0 & 11 & 17 & 0 & 28 \\
\hline Hasil PII & 0 & 39 & 61 & 0 & 100 \\
\hline $\begin{array}{l}\text { Relatif PII (\%) } \\
\text { Hasil PIII }\end{array}$ & 0 & 8 & 20 & 0 & 28 \\
\hline $\begin{array}{l}\text { Relatif PIII } \\
\text { \%) }\end{array}$ & 0 & 28,57 & 71,43 & 0 & 100 \\
\hline
\end{tabular}

Tabel 7. menyajikan data distribusi pencapaian psikomotorik peserta didik pada pertemuan I, II, dan pertemuan III, atau selama pembelajaran berbasis inkuiri terbimbing berlangsung. Pada pertemuan I, frekuensi pada interval 19 - 33 (Gagal) dengan jumlah 0 , yaitu sebesar $0 \%$, interval $34-47$ (Kurang Berhasil) dengan jumlah frekuensi 10 , yaitu sebesar $35,71 \%$, interval 48 - 61 (Berhasil) dengan jumlah frekuensi 18, yaitu sebesar 64,29\%, dan frekuensi pada interval $62-76$ (Sangat Berhasil) dengan jumlah 0 , yaitu sebesar $0 \%$.

Pada pertemuan II, Pada pertemuan II, frekuensi pada interval $19-33$ (Gagal) dengan jumlah 0 , yaitu sebesar $0 \%$, interval $34-47$ (Kurang Berhasil) dengan jumlah frekuensi 11, yaitu sebesar 39\%, interval 48 - 61 (Berhasil) dengan jumlah frekuensi 17, yaitu sebesar 61\%, dan frekuensi pada interval 62 - 76 (Sangat Berhasil) dengan jumlah 0, yaitu sebesar 0\%. Sedangkan untuk pertemuan III, frekuensi pada interval 
19 - 33 (Gagal) dengan jumlah 0, yaitu sebesar 0\%, interval $34-47$ (Kurang Berhasil) dengan jumlah frekuensi 8 , yaitu sebesar 28,57\%, interval 48 - 61 (Berhasil) dengan jumlah frekuensi 20, yaitu sebesar $21,43 \% \%$, dan frekuensi pada interval $62-$ 76 (Sangat Berhasil) dengan jumlah 0, yaitu sebesar $0 \%$.

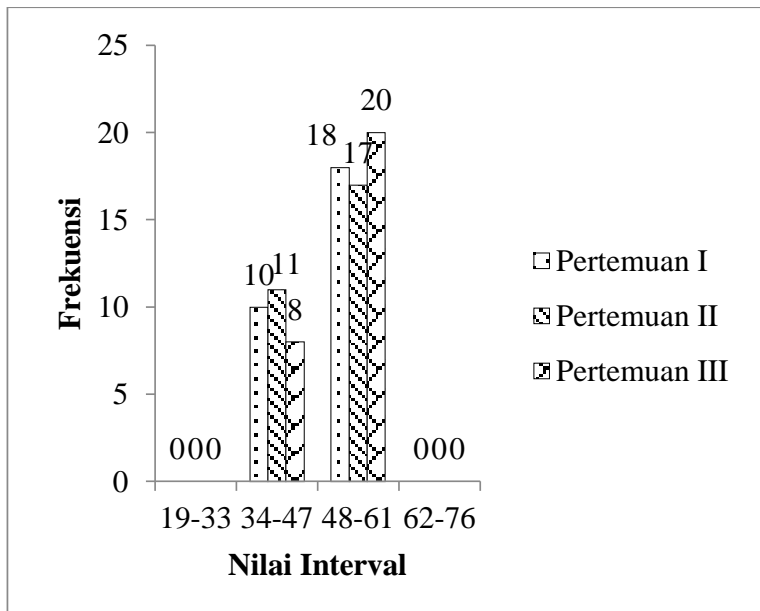

Gambar 2. Histogram Distribusi Frekuensi Pencapaian Psikomotorik

Tabel 8. Ringkasan Hasil Analisis Nilai Psikomotorik Tiap Pertemuan

\begin{tabular}{|c|c|c|c|c|}
\hline $\begin{array}{l}\text { Yang } \\
\text { diuji }\end{array}$ & $\begin{array}{c}\text { Jenis } \\
\text { uji }\end{array}$ & Hasil & $\begin{array}{c}\text { Kepu- } \\
\text { tusan }\end{array}$ & Kesimpulan \\
\hline $\begin{array}{c}\text { Hasil } \\
\text { Psiko- } \\
\text { motori } \\
\text { k } 3 \\
\text { Perte- } \\
\text { muan }\end{array}$ & $\begin{array}{c}\text { Uji } \\
\text { Frie } \\
\text { dma } \\
n\end{array}$ & $\begin{array}{c}\mathrm{t}_{\text {hitung }} \\
= \\
8,725 \\
\mathrm{p}= \\
0.01 \\
3\end{array}$ & $\begin{array}{c}\text { H0 } \\
\text { ditolak }\end{array}$ & $\begin{array}{l}\text { Hasil tidak } \\
\text { sama (ada } \\
\text { perbedaan) }\end{array}$ \\
\hline
\end{tabular}

Berdasarkan Tabel 8., diketahui $\mathrm{t}_{\text {hitung }}$ adalah 8,725 sedangkan untuk $t_{\text {tabel }}(0,05 ; 2)$ adalah 1,386. Oleh karena $t_{\text {hitung }}>t_{\text {tabel }}$ atau dengan melihat probabilitas sebesar 0,013 (p $<0,05)$, maka Ho ditolak. Hal ini berarti bahwa hasil penilaian psikomotorik tiap pertemuan tidak sama, atau dengan ungkapan lain dapat dikatakan bahwa terdapat perbedaan yang signifikan antara pertemuan I, II, dan pertemuan III. Melihat nilai rerata psikomotorik tiap pertemuan yang semakin baik pada Tabel 6., dapat diketahui bahwa pembelajaran berbasis inkuiri terbimbing terintegrasi pendidikan karakter dapat meningkatkan kemampuan psikomotorik peserta didik pada materi cahaya dan optika.

\section{3) Penilaian Afektif}

Data hasil penilaian afektif peserta didik yang diperoleh dari 3 kali pertemuan pada kelas uji coba diperluas, dideskripsikan pada Tabel 9.

Tabel 9. Deskripsi Data Pencapaian Afektif Peserta Didik

\begin{tabular}{cccccc}
\hline Pertemuan & N & Mean & Mean & \multicolumn{2}{c}{ SD Min. } \\
\hline I & 28 & 10,14 & 1,63 & 7 & 13 \\
\hline II & 28 & 10,57 & 1,07 & 8 & 12 \\
\hline III & 28 & 11,32 & 1,46 & 9 & 14 \\
\hline
\end{tabular}

Tabel 9. menyajikan data pencapaian afektif peserta didik selama pembelajaran berbasis inkuiri terbimbing berlangsung. Pada pertemuan pertama, hasil rerata yang diperoleh adalah 10,14 dengan standar deviasi 1,63 , nilai terendah 7 dan tertinggi 13. Pada pertemuan kedua, hasil rerata yang diperoleh adalah 10,57 dengan standar deviasi 1,07, nilai terendah 8 dan tertinggi 12. Pada pertemuan ketiga, hasil rerata yang diperoleh adalah 11,32 dengan standar deviasi 1,46 , nilai terendah 9 dan tertinggi 14.

Tabel 10. menyajikan data distribusi pencapaian afektif peserta didik pada pertemuan I, II, dan pertemuan III, atau selama pembelajaran berbasis inkuiri terbimbing berlangsung. Pada pertemuan I, frekuensi pada interval $4-7$ (Belum Terlihat) dengan jumlah frekuensi 2, yaitu sebesar 7,1\%, interval $8-10$ (Mulai 
Terlihat) dengan jumlah frekuensi 12 , yaitu sebesar 42,9\%, interval $11-13$ (Mulai Berkembang) dengan jumlah frekuensi 14, yaitu sebesar 50\%, dan frekuensi pada interval 14 - 16 (Membudaya) dengan jumlah 0 , yaitu sebesar $0 \%$.

Tabel 10. Distribusi Pencapaian Afektif Peserta Didik

\begin{tabular}{lcccccc} 
Nilai Interval & $4-7$ & $8-10$ & $11-13$ & $14-16$ & \multirow{2}{*}{ Jumlah } \\
\cline { 1 - 6 } Kategori & $\begin{array}{c}\text { Belum } \\
\text { Terlihat }\end{array}$ & $\begin{array}{c}\text { Mulai } \\
\text { Terlihat }\end{array}$ & $\begin{array}{c}\text { Mulai } \\
\text { Berkembang }\end{array}$ & $\begin{array}{c}\text { Mem- } \\
\text { budaya }\end{array}$ & \\
\hline Hasil PI & 2 & 12 & 14 & 0 & 28 \\
\hline Relatif PI (\%) & 7,1 & 42,9 & 50 & 0 & 100 \\
\hline Hasil PII & 0 & 13 & 15 & 0 & 28 \\
\hline Relatif PII (\%) & 0 & 46,43 & 53,57 & 0 & 100 \\
\hline Hasil PIII & 0 & 8 & 17 & 3 & 28 \\
\hline Relatif PIII (\%) & 0 & 28,58 & 60,71 & 10,71 & 100 \\
\hline
\end{tabular}

Pada pertemuan II, frekuensi pada interval $4-7$ (Belum Terlihat) dengan jumlah frekuensi 0, yaitu sebesar 0\%, interval $8-10$ (Mulai Terlihat) dengan jumlah frekuensi 13, yaitu sebesar 46,43\%, interval $11-13$ (Mulai Berkembang) dengan jumlah frekuensi 15, yaitu sebesar $53,57 \%$, dan frekuensi pada interval $14-16$ (Membudaya) dengan jumlah 0, yaitu sebesar 0\%. Sedangkan untuk pertemuan III, frekuensi pada interval $4-7$ (Belum Terlihat) dengan jumlah frekuensi 0 , yaitu sebesar $0 \%$, interval $8-10$ (Mulai Terlihat) dengan jumlah frekuensi 8 , yaitu sebesar 25,58\%, interval $11-13$ (Mulai Berkembang) dengan jumlah frekuensi 17, yaitu sebesar 60,71\%, dan frekuensi pada interval 14 - 16 (Membudaya) dengan jumlah 3, yaitu sebesar 10,71\%.

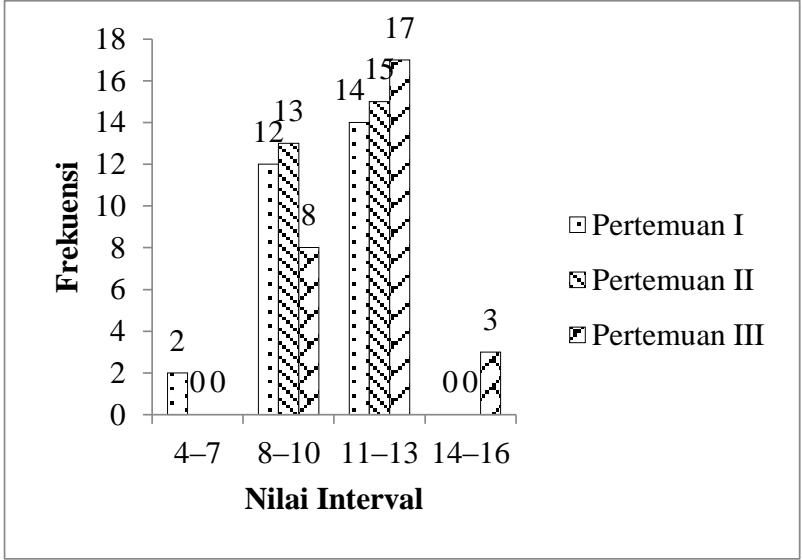

Gambar 3. Histogram Distribusi Frekuensi Pencapaian Afektif

Tabel 11. Ringkasan Hasil Uji Afektif Tiap Pertemuan

\begin{tabular}{ccccc}
\hline $\begin{array}{c}\text { Yang } \\
\text { diuji }\end{array}$ & $\begin{array}{c}\text { Jenis } \\
\text { uji }\end{array}$ & Hasil & $\begin{array}{c}\text { Keput } \\
\text { u-san }\end{array}$ & $\begin{array}{c}\text { Kesimpul } \\
\text { an }\end{array}$ \\
\hline \multicolumn{5}{c}{$\mathrm{t}_{\text {hitung }}$} \\
$=$ & & \\
Hasil & Uji & 12,02 & H0 & Hasil tidak \\
Afektif 3 & Friedma & 4 & ditolak & sama (ada \\
Pertemu & $\mathrm{n}$ & $\mathrm{p}=$ & & perbedaan) \\
an & & 0.00 & & \\
& & 2 &
\end{tabular}

Berdasarkan Tabel 11., diketahui $t_{\text {hitung }}$ adalah 12,024 sedangkan untuk $t_{\text {tabel }}(0,05 ; 2)$ adalah 1,386. Oleh karena $t_{\text {hitung }}>t_{\text {tabel }}$ atau dengan melihat probabilitas sebesar 0,002 (p 
$<0,05)$, maka Ho ditolak. Hal ini berarti bahwa hasil penilaian afektif tiap pertemuan tidak sama, atau dengan ungkapan lain dapat dikatakan bahwa terdapat perbedaan yang signifikan antara pertemuan I, II, dan pertemuan III. Melihat nilai rerata afektif tiap pertemuan yang semakin baik pada Tabel 4.15., dapat diketahui bahwa pembelajaran berbasis inkuiri terbimbing terintegrasi pendidikan karakter dapat meningkatkan kemampuan afektif peserta didik pada materi cahaya dan optika.

\section{PEMBAHASAN}

\section{1) Hasil Belajar Kognitif}

Kesimpulan yang telah diperoleh dari pengujian hasil pretes dan postes (hasil belajar kognitif) pada Tabel 5, bahwa terdapat perbedaan yang signifikan antara hasil belajar peserta didik sebelum (pretes) dan sesudah diberikan perlakuan (postes), serta terdapat peningkatan rerata yaitu sebesar 49,95 untuk rerata pretes dan sebesar 52,31 untuk rerata postes, mengartikan sebuah keberhasilan dalam proses pembelajaran yang telah dilalui oleh peserta didik dengan pemberian perlakuan pembelajaran berbasis inkuiri terbimbing. Amirin (2012), mengungkapkan bahwa keberhasilan proses pembelajaran peserta didik dipengaruhi oleh beberapa faktor yang salah satu diantaranya adalah pendekatan atau metode yang digunakan oleh guru. Penggunaan metode inkuiri terbimbing yang telah diaplikasikan di kelas, dianggap tepat sehingga dapat meningkatkan hasil belajar kognitif peserta didik. Terkait dengan penggunaan metode inkuiri sebagai basis kegiatan pembelajaran, Minner, et al. (2009) dalam penelitiannya menemukan bahwa penggunaan metode inkuiri sebagai basis dari kegiatan pembelajaran, selain akan memenuhi standar penilaian pendidikan (kognitif, afektif, dan psikomotorik), juga akan lebih meningkatkan pemahaman konseptual peserta didik. Peningkatan hasil belajar kognitif tersebut juga menunjukkan adanya suatu usaha dari peserta didik untuk lebih mengerti akan materi yang sedang dipelajari. Usaha tersebut terlihat dalam kegiatan pembelajaran yang aktif, peserta didik selalu bertanya, dan menggali informasi lain selain yang telah didapatkan dari guru.

Peran guru selama berlangsungnya proses pembelajaran juga menjadi salah satu faktor yang mempengaruhi peningkatan kemampuan kognitif peserta didik, hal ini dikarenakan guru lebih menempatkan dirinya sebagai motivator dan fasilitator. Hal ini sejalan dengan yang telah disampaikan oleh Trianto (2011), bahwa pada pembelajaran inkuiri, sebaiknya guru mengambil 7 peranan penting agar tercipta pembelajaran inkuiri yang optimal, yaitu sebagai motivator, fasilitator, penanya, administrator, pengarah, manajer, dan rewarder.

\section{2) Hasil Penilaian Psikomotorik}

Hasil uji terhadap penilaian psikomotorik yang disajikan pada Tabel 6 menyimpulkan terdapat perbedaan yang signifikan terhadap pencapaian psikomotorik peserta didik antara pertemuan I, II, dan pertemuan III serta terdapat peningkatan pencapaian secara rerata hasil psikomotorik peserta didik dalam setiap pertemuan, yaitu sebesar 47,68 untuk pertemuan I, 48,70 untuk pertemuan II, dan sebesar 48,79 untuk pertemuan III. Selain itu, frekuensi pencapaian psikomotorik terbanyak peserta didik, berada pada pencapaian (kategori) "Berhasil". Pencapaian tersebut, disebabkan oleh peserta didik yang terlibat secara aktif ketika pembelajaran menggunakan inkuiri terbimbing dan terintegrasi pendidikan karakter berlangsung serta guru yang telah tepat dalam mengambil peran selama proses pembelajaran berlangsung.

Pencapaian tersebut menurut Uno (2008) merupakan penyebab pokok terbentuknya respons-respons dalam belajar yang dinamakan operant conditioning. Hal 
tersebut dibentuk melalui pengubahan materi bahasan sedemikian rupa sehingga dapat merangsang pembelajar mengembangkan perilaku seperti yang dikehendaki dalam tujuan belajar. Sebagai pengembangan dan konsepsi classical conditioning yang mengabaikan jarak antara stimulus (S) dan respons (R), operant conditioning sesungguhnya merupakan sinyal-sinyal penggerak pikiran dan dipandang sebagai mediator dari yang diinginkan pemberi stimulus dengan harapan penerima mengembangkan reaksi pikiran dan tindakan-tindakan tertentu.

Motivasi dan arahan yang diberikan oleh guru kepada peserta didik adalah faktor yang paling dominan berpengaruh terhadap meningkatnya pencapaian psikomotorik peserta didik. Pada pertemuan I, guru belum mengambil perannya sebagai motivator dan pengarah, sehingga sebagian peserta didik belum melibatkan dirinya secara aktif dan antusias dalam proses kegiatan pembelajaran. Sedangkan pada pertemuanpertemuan berikutnya, guru telah menyadari perannya tersebut, sehingga terjadi peningkatan kualitas pembelajaran yang menyebabkan rerata pencapaian psikomotorik peserta didik juga meningkat.

Peran guru sebagai motivator dan pengarah, dijelaskan lebih lanjut oleh Trianto (2011), bahwa motivasi dan arahan yang diberikan oleh guru pada pembelajaran inkuiri akan memberikan rangsangan kepada peserta didik untuk terlibat aktif dan bergairah untuk berpikir serta memimpin kegiatan yang dilakukan oleh peserta didik untuk mencapai tujuan yang diharapkan. Sehingga keterampilan psikomotorik yang diharapkan, dapat terlihat secara optimal dan berkembang dari pertemuan satu ke pertemuan berikutnya.

\section{3) Hasil Penilaian Afektif (karakter)}

Hasil uji terhadap penilaian afektif yang disajikan pada Tabel 6 menyimpulkan terdapat perbedaan yang signifikan antara pertemuan I, II, dan pertemuan III serta terdapat peningkatan pencapaian secara rerata hasil afektif peserta didik dalam setiap pertemuan, yaitu sebesar 10,14 untuk pertemuan I, 10,57 untuk pertemuan II, dan sebesar 11,32 untuk pertemuan III. Selain itu, frekuensi pencapaian afektif terbanyak peserta didik, berada pada pencapaian (kategori) "Mulai Berkembang". Hal ini sejalan dengan temuan Mundilarto, et al. (2010), bahwa kegiatan pembelajaran dengan pendekatan inkuiri terbimbing, mampu menghasilkan peningkatan pada sikap ilmiah (afektif) peserta didik. Beberapa hal yang mempengaruhi pencapaian tersebut adalah guru yang tidak menggunakan metode indoktrinasi, tapi inkulkasi (penanaman). Selain itu, nilai-nilai tersebut tidaklah diajarkan, tetapi dikembangkan.

Selain metode inkulkasi dan pengembangan nilai, guru juga memberikan teladan yang baik sebagai metode tambahan untuk mendidik karakter peserta didik. Cara guru menyelesaikan masalah secara adil, mengungkapkan pendapat, menjawab pertanyaan, menghargai pendapat peserta didik, menggunakan bahasa yang santun, dan cara guru menghargai peserta didik dengan menganggapnya sebagai kertas putih yang siap untuk diwarnai dengan ilmu pengetahuan, adalah beberapa hal yang dapat dijadikan alasan bagi peserta didik untuk meneladani gurunya.

Flurnoy (2009) dalam penelitiannya mengungkapkan bahwa memfasilitasi peserta didik dengan lingkungan yang nyaman, akan mengembangkan karakter peserta didik dan mampu meningkatkan prestasi belajar mereka. Hal ini dikarenakan lingkungan yang nyaman akan mengubah pola perilaku peserta didik dalam belajar secara positif. Lingkungan yang nyaman tersebut, dapat diciptakan di rumah maupun di sekolah. Hal yang diungkapkan oleh Flurnoy (2009) tersebut, mengindikasikan faktor selain metode dalam mengembangkan karakter peserta didik. Brown (2008) tidak mempermasalahkan bagaimana metode atau cara yang tepat dalam mendidik karakter 
peserta didik. Menurutnya dengan cara apa pun, pendidikan karakter akan mempengaruhi perilaku peserta didik.

Pendidikan karakter yang baik, seharusnya di mulai dari rumah, karena sekolah hanya membantu peserta didik untuk mengembangkan karakter. Penelitian yang dilakukan oleh Martinson (2003) menemukan bahwa pendidikan karakter yang di mulai dari rumah, akan mencerminkan perilaku peserta didik di sekolah, kemudian guru akan membantu untuk mengembangkan dan mendidik karakter dengan menstimulasi imajinasi moral, sehingga peserta didik dapat mengidentifikasi bahwa perilaku tersebut baik atau tidak baik.

\section{KESIMPULAN}

Berdasarkan data hasil penelitian yang telah dilakukan, dapat disimpulkan bahwa pembelajaran inkuiri terbimbing terintegrasi pendidikan karakter dapat meningkatkan hasil belajar fisika peserta didik pada aspek kognitif, afektif, dan psikomotorik yang dibuktikan dengan perhitungan statistik.

\section{REFERENSI}

Amirin, Siti. (2012). Pembelajaran Biologi Model Children's Learning in Science Melalui Inkuiri Terbimbing dan Inkuiri Bebas Termodifikasi Ditinjau dari Sikap Ilmiah dan Kemampuan Berpikir Kritis. Tesis. UNS. (Unpublished).

Brown, Chelsea. (2008). Character Education and Its Impact on Student Behavior. ProQuest Education Journal. 33 (2), 40.

Flurnoy, Torie. (2009). Character Education and The Perceived Impact on Student
Academic Achievement. ProQuest Education Journal. 35 (4), 18.

Hamalik, Oemar., (2009), Proses Belajar Mengajar. PT. Jakarta: Bumi Aksara.

Koesoema, Doni. (2010). Pendidikan Karakter: Kajian Teori dan Praktik di Sekolah. Bandung: Rosda.

Kemendiknas. (2010). Bahan Pelatihan: Penguatan Metodologi Pembelajaran Berdasarkan Nilai-nilai Budaya Untuk Membentuk Daya Saing dan Karakter Bangsa. Jakarta: Kemendiknas RI.

Kuhlthau, C. C. Maniotes, L. K., \& Caspari. A. K. (2007). Guided inquiry: Learning in the 21st century. Santa Barbara, CA: Libraries Unlimited.

Martinson, David L. (2003). High School Students and Character Education: It All Starts at Wendy's. ProQuest Education Journal. 27 (1), 14.

Minner, D.D, Levy, A.J, dan Century, J. (2009). Inquiry Based Science Instruction-What is and does it Matter? Results from a Research Synthesis years 1984 to 2002. Journal of Research in Science Teaching. 47 (4), 474.

Mundilarto. (2010). Inquiry-Based Learning dan Pengembangan Perangkat Pembelajarannya. Laporan Penelitian Pengembangan Ilmu Guru Besar. UNY. Yogyakarta. (Unpublished).

Panjaitan, Suhendry. (2011). Pengaruh

Strategi Pembelajaran Inkuiri

Terbimbing

Terintegrasi Pendidikan Karakter Terhadap Hasil Belajar Kimia Siswa SMA.. Skripsi. Unimed. (Unpublished).

Suyatna, Agus. (2015). Pembelajaran IPA Wahana untuk Menumbuhkan Kemampuan Berpikir, Bersikap, dan 
Bertindak Ilmiah. Bandar Lampung: Uno, Hamzah B. (2008). Orientasi Baru Universitas Lampung.

Trianto. (2011). Mendesain Model Pembelajaran Inovatif-Progresif: dalam Psikologi Pembelajaran. Jakarta: Bumi Aksara.

Konsep, Landasan, dan Implementasinya Pada Kurikulum Tingkat Satuan Pendidikan (KTSP). Jakarta: Kencana. 